\title{
Study on the isolation and characterization of rhizobia strains as biofertilizer tools for growth improvement of four grain legumes in Ngaoundéré-Cameroon
}

\author{
A. NGAKOU ${ }^{1^{*}}$, C. MEGUENI ${ }^{1}$, H. OUSSENI ${ }^{1}$ and A. MASSAI ${ }^{1}$ \\ ${ }^{1}$ Department of Biological Sciences, Faculty of Science, University of Ngaoundéré, \\ P.O. Box 454 Ngaoundéré, Cameroon. \\ *Corresponding author, E-mail: alngakou@yahoo.fr
}

\begin{abstract}
Increasing the yield and economical efficiency of grain legumes in the Guinea-Savannah zone of Cameroon is a high researcher priority to assist growers in the rural areas. We report here a two-years study in the production process of fertilizer containing rhizobia for a sustainable production of grain legumes in the region. To address the issue, nodulation and rhizobia strains characterization were assessed at Dang and Wakwa, two soils different in trapping rhizobia partners for groundnut, bambara groundnut, cowpea and soybean. This was a prerequisite step in the determination of the most efficient rhizobia strains for biofertilizer production. Results indicate that all the four grain legumes differently formed nodules in their roots system in the two experimental soils. Cowpea and soybean demonstrated a highly significant $(\mathrm{p} \leq 0.001)$ potential in fixing atmospheric nitrogen through their nodules than groundnut and bambara groundnut. The dry weight of nodules in groundnut and bambara groundnut was significantly lower $(0.0001<\mathrm{p} \leq 0.038)$ than that of cowpea and soybean in the two soils. When rhizobia were isolated from root nodules of plant species, the number of isolates ranged from 2 to 4 per grain legumes. All the isolates were convex in elevation, smooth/humid on the surface, with regular edges, except one groundnut colony from wakwa soil. The colonies were either whitish for soybean, whitish/yellowish for cowpea, groundnut and bambara groundnut. The rhizobia biofertilizer produced for each grain legumes were stored in the refrigerator for field tests. This is a step forward for further molecular characterization of isolates to enable production of elite inoculum in the region.
\end{abstract}

(C) 2009 International Formulae Group. All rights reserved.

Key words: Grain legumes, nodulation, Rhizobium characterization, Rhizobium biofertilizer.

\section{INTRODUCTION}

Rhizobia are Gram negative bacteria that exist in a symbiotic relationship with several grain legumes as a host plants. In this association, the host plant provides the bacteria symbiont with sugars and a protected environment, while the bacteria fix nitrogen from the air and make it available to the plant in the form of ammonia (FAO, 1985; Kiers et al., 2002). In the Guinea-Savannah zone of Cameroon where the population diet is mostly based on cereals, there is a need to improve the production of common grain legumes such as cowpea, bambara groundnut, groundnut and soybean through inoculation technology, if full benefit from these crops is to be achieved in terms of maximum yield and soil fertility.

Legumes play a critical role in natural ecosystems, agriculture, and agroforestry, where their ability to fix $\mathrm{N}$ in symbiosis makes them excellent colonizers of low- $\mathrm{N}$ environments, and economically friendly crop, pasture, and tree species (Jensen and Hauggaard-Nielsen, 2002). In addition to its role as a source of protein in the diet, $\mathrm{N}$ from legume fixation is essentially "free" for use by the host plant and by associated or subsequent crops (Kiers et al., 2002). Legumes also have positive effects on agriculture by adding and recycling biologically fixed $\mathrm{N}_{2}$, enhancing nutrient uptake, reducing greenhouse gas 
emissions by reducing $\mathrm{N}$-fertilizer use, and breaking non-legume crop pest cycles (Zahran, 1999; Lupwayi and Kennedy, 2007). Legume yields unfortunately continue to lag behind those of cereals. A research orientation that better balances the needs of sustainable oriented agriculture with the breakthrough low-cost technologies such as rhizobial inoculation is required (Hirsch et al., 2001). Most grain legumes produced by small holder farmers are not often inoculated with rhizobia or applied with fertilizers (Ogendo and Joshua, 2001).

To date, there has been only limited commercial use of plant growth-promoting bacteria in agriculture and horticulture (Vessey, 2003). However, with recent progress towards understanding the mechanisms that these organisms utilize to facilitate plant growth, the use of plant growth-promoting bacteria is expected to continue to increase worldwide (Arshad. and Frankenberger, 1993; Cheng, 2003). Generally, grain legumes do not need additional nitrogen if the seed is effectively inoculated at planting. Inoculation with the most efficient $\mathrm{N}$-fixing bacteria for the type of legume is necessary to help maximise nodulation and N-fixing ability (Pal and Shehu, 2001). In fact, rhizobia are randomly distributed in growing soils where they compete with other indigenous strains (Denison and Kiers, 2004), which often form less efficient nodules (Simms and Taylor, 2002). However, the mechanisms which determine the relative competitiveness among strains are still poorly understood (Kober et al., 2004). The study of Glycine max-rhizobia association in the Guinea-savannah zone of Cameroon has revealed the efficiency of indigenous strains over the exotic ones (Megueni et al., 2006), although these later showed efficiency in other agroecological zones for Vigna unguiculata (Ngakou, 2007). Rhizobia are fairly specific as to which legumes they will infect, form nodules on the roots of, and for which they will fix nitrogen (Lupwayi and Kennedy, 2007). In order to ensure the availability of the correct effective strain specific to a legume plant species, an inoculation practice should be performed, particularly when the legume being planted has not been grown in that field in at least the past three years or with every planting of a high value crop (Zdor and Pueppke, 1990). Researchers have sought for ways of improving nitrogen fixation and enhancing yield of grain legumes by selecting efficient strains for production of inoculants (Hynes et al., 2001). Vance and Graham (1995) emphasized the importance of understanding the characteristics of indigenous rhizobia populations as the prerequisite for inoculant production. These characteristics would be considered in the selection of strains which would be most adapted in a particular region.

The objectives of this study were to characterize and produce the native population of rhizobia nodulating four grain legumes in two soil types of Ngaoundéré. During this study, the most efficient strains would be selected and used to produce rhizobia biofertilizers. Such fertilizers are expected to improve the growth of grain legumes in the region.

\section{MATERIALS AND METHODS Study areas}

Experiments were conducted in Ngaoundéré within the Guinea savannah zone of Cameroon, from April to July in 2006 and 2007, and in two soil types (Dang and Wakwa). The Dang soil has pH 5.45, 0.16g N and $0.04 \mathrm{~g}$ P per $100 \mathrm{~g}$ of soil, while at Wakwa, the soil $\mathrm{pH}$ was 5.2 , with the $\mathrm{N}$ and $\mathrm{P}$ contents of respectively $0.26 \mathrm{~g}$ and $0.12 \mathrm{~g}$ per $100 \mathrm{~g}$ of soil. In each of the soil types four individual soil samples of $45 \mathrm{~kg}$ originated from selected farm fields were collected from the first $20 \mathrm{~cm}$ soil depth and bulked to form a $180 \mathrm{~kg}$ composite samples. Each composite soil sample was packaged into black plastic bags of $2 \mathrm{~kg}$.

\section{Grain legumes}

Seeds used in the trial were cowpea (Vigna unguiculata L. Walp.) seeds from Bafia in the Centre region of Cameroon with lifecycle of 85 to 95 days. C5 variety of soybean (Glycine max L.) seeds from Maïscam-Ngaoundéré (155 and 160 days), bambara groundnut (Vigna subterranea L. Verdc.) seeds from the Far North region of Cameroon (115 to 160 days), and groundnut (Arachis hypogea L.) seeds of the GH119-20 variety from IRAD-Maroua (90 to 110 days). 


\section{Experimental design}

The experimental design consists of a completely randomised block systems with four treatments (cowpea; bambara groundnut; groundnut; soybean), and two replicates (soils from Dang and soil from Wakwa). For a soil type, each treatment was represented by 20 free-draining plastic bags. Seeds were sown in May 2006, and the experiment repeated in May 2007 during the first growing season extending from April to July. In each of the 2 $\mathrm{kg}$ plastic bags containing non-sterilized soil, rhizobia were trapped using four seeds of each grain legume species. After germination, plantlets were thinned to three to increase the surface area of plantlets in plastic bags.

\section{Nodulation and plant biomass}

Nodulation efficiency was evaluated by enumerating the number and assessing the dry weight of viable nodules on 20 plants per treatment at 60 days after planting (Ngakou et al., 2007). Plants were carefully removed from the soil and the root system washed to enable better visualization of nodules. All root nodules collected from each of the 20 plants of the same grain legume were dried in a hotair oven for 12 hours at $60{ }^{\circ} \mathrm{C}$ and weighed separately. To assess the plant biomass, each plant was also dried for 72 hours at $60{ }^{\circ} \mathrm{C}$ and weighed (Athar and Johnson, 1996). To test the nitrogen fixation activity, 20 fresh nodules/plant species were cut open with blade and the colour observed. Depending on the grain legume species, the red, pink and/or green colours were recorded as from nitrogen fixing nodules while whitish colours were from non-nitrogen fixing ones. These colorations reflect the colour of leghemoglobine which is an indication within a root nodule that $\mathrm{N}$-fixation is taking place (Linderman, 2008).

\section{Isolation of rhizobia strains from fresh nodules}

Petri dishes were cleaned with tap water, rinsed with distilled water and allowed to dry at room temperature. Cleaned dishes were sterilized in the dry oven at $105^{\circ} \mathrm{C}$ for 2 hours. The Yeast Extract Mannitol Agar (YEMA) medium was prepared as described by Vincent (1970) with the following composistion: $10 \quad \mathrm{~g}$ mannitol; $0.2 \mathrm{~g}$
$\mathrm{MgSO}_{4}, 7 \mathrm{H}_{2} \mathrm{O} ; 1 \mathrm{~g}$ yeast extract; $0.5 \mathrm{~g}$ $\mathrm{KH}_{2} \mathrm{PO}_{4} / \mathrm{K}_{2} \mathrm{HPO}_{4} ; 0.1 \mathrm{~g} \mathrm{NaCl}$; distilled water $1 \mathrm{~L} ; \mathrm{pH}=6.8$. The medium was supplemented with $0.25 \%$ Congo Red for examination of possible contaminants. Rhizobia were isolated from the fresh root nodules as described by Somasegaran and Hoben (1985). Root nodules were immersed in $95 \%$ alcohol for $30 \mathrm{~s}$, and then in $0.1-0.2 \% \mathrm{HgCl}_{2}$ for $5 \mathrm{~min}$. Control nodules were whitish and were expected to contain no rhizobia. They were then sterilized in $70 \%$ alcohol for $1 \mathrm{~min}$ and rinsed again with distilled water to remove all traces of alcohol. Sterilized nodules were ground in a Petri dish using a sterile scapel. A loopful of ground nodule was sampled and struck onto the YEMA solid medium. Petri dishes inoculated for each soil type and each grain legume were incubated at room temperature. One week after the first streak, different colonies formed separately were sub-cultured onto the YEMA-Congo Red solid medium under the same conditions, in order to screen all the single colonies. One week after subculturing, the morpho-cultural characteristics of isolated colonies (number, elevation, surface, colour, aspect, edges) were determined by observation under a stereomicroscope (Seeley and VanDemark, 1989).

\section{Liquid culture and inoculum production}

In the YEMA-Congo Red liquid medium, agar was reduced from 15 to $1.5 \mathrm{~g} / \mathrm{l}$. The carrier substrate was made of ground charcoal, palm oil peat, vermiculite in the ratio 1:1:1 (w:w:w), and macroelements $(\mathrm{N}, \mathrm{P}$, $\mathrm{K}$ ) in micro-quantities. Isolated colonies from grain legume species (cowpea, soybean, bambara groundnut, graoundnut) under growth on solid medium were transferred into Erlenmeyer flasks containing $200 \mathrm{ml}$ YEMACongo Red liquid medium. Rhizobia were allowed to grow to $106-108$ cells $/ \mathrm{ml}$ for $48 \mathrm{~h}$ under shaking conditions on a magnetic stirrer. The carrier substrate was weighed (20 g) in heat-resistant white and transparent plastic sheets, wetted with $10 \mathrm{ml}$ distilled water and autoclaved at $121{ }^{\circ} \mathrm{C}$ for 25 minutes. The sterilized substrate was cooled down under the flux laminar hood where 20 $\mathrm{ml}$ liquid culture was thoroughly mixed with it and the package sealed immediately to 
prevent contamination. The rhizobia inoculum thus obtained was weighed and labelled as a specific grain legume inoculum.

\section{Statistical analysis}

Data were statistically subjected to analysis of variance (ANOVA) using a Statgraphic Plus, version 5.0 (SIGMA PLUS) computer program. Means were compared between treatments using the Duncan Multiple range test at $5 \%$ level.

\section{RESULTS}

Differential Nodulation and growth of grain legumes in Dang and Wakwa soils during the 2006 and 2007 cropping seasons

Data on nodulation efficiency of the four grain legumes at Dang and Wakwa soils are presented in tables 1 and 2. All the four grain legumes formed nodules on their roots during the two growing seasons in Dang soil (Table 2). Whereas bambara groundnut and cowpea significantly produced more nodules than soybean and groundnut in 2006, the number of nodules produced by bambara groundnut was significantly lower $(\mathrm{p}<$ 0.0001) than that of cowpea, soybean and groundnut in 2007. Root nodules were red or pink for cowpea, groundnut and bambara groundnut, and greenish for soybean. Cowpea and soybean showed significantly ( $\mathrm{p}<$ $0.0001)$ greater potential in fixing atmospheric nitrogen through their nodules than groundnut and bambara groundnut. Among the four grain legumes, soybean had a significantly higher biomass than cowpea or groundnut at 60 days after planting during the two growing seasons in Dang soil.

In Wakwa, soybean and groundnut produced more nodules than bambara groundnut and cowpea in 2007, while the reverse situation occurred in 2006 (Table 2). The dry weight of nodules in groundnut and bambara groundnut was once more lower than that of cowpea and soybean during the two growing seasons. Soybean was the only grain legume able to fix more nitrogen than the other three in both soils.

During the 2006 growing season, the ability of bambara groundnut $(\mathrm{p}=0.34)$ and soybean $(\mathrm{p}=0.66)$ to fix atmospheric nitrogen did not significantly differ between Dang and Wakwa soils. Conversely, cowpea nodules (p
$=0.027)$ and groundnut nodules $(p=0.007)$ were more efficient in fixing nitrogen in Wakwa than in Dang soil. All the four grain legumes grown in Wakwa significantly ( $\mathrm{p} \leq$ 0.044 ) produced more root nodules than those raised from Dang soil. However, the dry weights of nodules were the same for cowpea and bambara groundnut in the two trapping soils. The dry weight of nodules on soybean and groundnut were significantly ( $\mathrm{p} \leq 0.037$ ) greater in Wakwa than in Dang soils. Just like the number of nodules, the biomass of grain legumes at 60 days after planting was significantly lower $(\mathrm{p} \leq 0.047)$ in Dang than Wakwa soils.

During the 2007 cropping season, the number and dry weight of nodules per plant, the capacity of plant species to fix nitrogen, and the plant biomass did not significantly differ ( $p>0.05$ ) between the two soils for cowpea and soybean. However, all these parameters were significantly different $(\mathrm{p} \leq$ 0.038) between the two soils for bambara groundnut and groundnut, except for the number of nodules in groundnut $(\mathrm{p}=0.17)$.

There was a positive and significant correlation between the number of nodules and the biomass of plants for groundnut grown in Dang soil $(\mathrm{r}=0.80 ; \mathrm{P}=0.005)$, while for bambara groundnut, this correlation was observed between the plant biomass and the efficiency of nodules $(r=0.80 ; \mathrm{P}=0.005)$ in Wakwa soil. Similarly, a significant correlation occurred between the number and dry weight of nodules in Dang $(\mathrm{r}=0.78$; $\mathrm{p}<$ $0.01)$ and Wakwa $(r=0.84 ; \mathrm{p}<0.05)$ soils for groundnut. For cowpea and soybean, there was also a positive and significant correlation between the number and efficiency of nodules with $(\mathrm{r}=0.63 ; \mathrm{p}<0.05)$ and $(\mathrm{r}=0.64 ; \mathrm{p}<$ $0.05)$ respectively.

\section{Morphological Characterization of rhizobia colonies}

Rhizobia isolated from each of the four grain legumes were characterized on YEMACongo Red solid medium by comparing the number, elevation, aspect, edge, surface and colour of colonies (Table 3). The number of colonies was either the same or differed from one grain legume to another and from one soil type to another. In cowpea and bambara groundnut two and three colonies were 
A. NGAKOU et al. / Int. J. Biol. Chem. Sci. 3(5): 1078-1089, 2009

Table 1: Differential growth and nodulation of bambara groundnut, cowpea, groundnut and soybean in Dang soil.

\begin{tabular}{|c|c|c|c|c|c|c|c|c|}
\hline \multirow[b]{2}{*}{ Treatments } & \multicolumn{2}{|c|}{$\begin{array}{c}\text { Number of Nodules } \\
\left(\text { plant }^{-1}\right)\end{array}$} & \multicolumn{2}{|c|}{$\begin{array}{l}\text { Nodules dw } \\
\text { (g.plant }^{-1} \text { ) }\end{array}$} & \multicolumn{2}{|c|}{$\begin{array}{c}\text { Efficiency of nodules } \\
(\%)\end{array}$} & \multicolumn{2}{|c|}{$\begin{array}{l}\text { Plant dw } \\
\left(\text { g.plant }^{-1}\right)\end{array}$} \\
\hline & 2006 & 2007 & 2006 & 2007 & 2006 & 2007 & 2006 & 2007 \\
\hline Cowpea & $10.1 \pm 0.40 \mathrm{~b}$ & $103.1 \pm 15.26 \mathrm{ab}$ & $0.55 \pm 0.05 b$ & $0.71 \pm 0.02 \mathrm{~b}$ & $62.44 \pm 2.44 b$ & $72.25 \pm 2.86 \mathrm{~b}$ & $5.51 \pm 0.68 \mathrm{a}$ & $5.87 \pm 0.60 \mathrm{a}$ \\
\hline Bambara & $9.9 \pm 0.37 b$ & $9.1 \pm 2.07 \mathrm{a}$ & $0.38 \pm 0.02 \mathrm{a}$ & $0.51 \pm 0.07 \mathrm{a}$ & $57.79 \pm 3.90 \mathrm{ab}$ & $51.38 \pm 7.41 \mathrm{a}$ & $10.32 \pm 0.77 \mathrm{~b}$ & $11.07 \pm 3.52 \mathrm{ab}$ \\
\hline Groundnut & $7.9 \pm 0.27 \mathrm{a}$ & $148.1 \pm 18.59 b$ & $0.30 \pm 0.02 \mathrm{a}$ & $0.45 \pm 0.03 \mathrm{a}$ & $51.21 \pm 2.61 \mathrm{a}$ & $45.74 \pm 3.23 \mathrm{a}$ & $4.99 \pm 0.45 \mathrm{a}$ & $5.61 \pm 0.51 \mathrm{a}$ \\
\hline Soybean & $7.2 \pm 0.41 \mathrm{a}$ & $143.8 \pm 20.31 b$ & $0.61 \pm 0.03 b$ & $0.75 \pm 0.06 \mathrm{~b}$ & $82.63 \pm 2.72 \mathrm{c}$ & $84.66 \pm 3.11 \mathrm{c}$ & $11.18 \pm 0.73 b$ & $17.98 \pm 2.54 \mathrm{~b}$ \\
\hline P-value & $<0.0001$ & $<0.0001$ & $<0.0001$ & 0.001 & $<0.0001$ & $<0.0001$ & $<0.0001$ & $<0.0009$ \\
\hline
\end{tabular}

Table 2: Differential growth and nodulation of bambara groundnut, cowpea, groundnut and soybean in Wakwa soil.

\begin{tabular}{|c|c|c|c|c|c|c|c|c|}
\hline \multirow[b]{2}{*}{ Treatments } & \multicolumn{2}{|c|}{$\begin{array}{c}\text { Number of Nodules } \\
\left(\text { plant }^{-1}\right)\end{array}$} & \multicolumn{2}{|c|}{$\begin{array}{l}\text { Nodules dw } \\
\text { (g.plant }^{-1} \text { ) }\end{array}$} & \multicolumn{2}{|c|}{$\begin{array}{c}\text { Efficiency of nodules } \\
\text { (\%) }\end{array}$} & \multicolumn{2}{|c|}{$\begin{array}{l}\text { Plant dw } \\
\left(\text { g.plant }^{-1} \text { ) }\right.\end{array}$} \\
\hline & 2006 & 2007 & 2006 & 2007 & 2006 & 2007 & 2006 & 2007 \\
\hline Cowpea & $19.3 \pm 1.94 b$ & $93.4 \pm 7.29 b$ & $0.5 \pm 0.03 b$ & $0.62 \pm 0.03 \mathrm{a}$ & $66.12 \pm 4.20 \mathrm{a}$ & $62.33 \pm 3.14 \mathrm{a}$ & $7.65 \pm 0.73 a$ & $9.39 \pm 1.38$ \\
\hline Bambara & $20.3 \pm 2.88 b$ & $15.6 \pm 3.20 \mathrm{a}$ & $0.34 \pm 0.02 \mathrm{a}$ & $0.61 \pm 0.08 \mathrm{a}$ & $66.30 \pm 3.15 \mathrm{a}$ & $61.60 \pm 8.22 \mathrm{a}$ & $15.03 \pm 0.80 \mathrm{~b}$ & $15.96 \pm 1.86 \mathrm{~b}$ \\
\hline Groundnut & $12.3 \pm 2.01 \mathrm{a}$ & $196.2 \pm 28.91 \mathrm{c}$ & $0.47 \pm 0.05 b$ & $0.66 \pm 0.04 \mathrm{ab}$ & $70.67 \pm 3.70 b$ & $66.99 \pm 4.85 \mathrm{ab}$ & $16.79 \pm 0.12 b$ & $12.15 \pm 1.35 b$ \\
\hline Soybean & $11.5 \pm 1.10 \mathrm{a}$ & $103.0 \pm 7.23 \mathrm{~b}$ & $0.47 \pm 0.03 b$ & $0.88 \pm 0.01 b$ & $84.29 \pm 2.58 \mathrm{c}$ & $88.99 \pm 1.79 b$ & $21.94 \pm 0.71 \mathrm{c}$ & $23.81 \pm 2.39 \mathrm{c}$ \\
\hline $\mathrm{P}$-value & 0.006 & $<0.0001$ & 0.038 & 0.001 & 0.001 & 0.001 & 0.06 & 0.002 \\
\hline
\end{tabular}

Values in the same column of a cropping season followed by the same letter for each parameter are not significantly different at $5 \%$ level. Data are mean \pm se (standard error of individual) of 20 samples; Nodules dw: Nodules dry weight; Plant dw: Plant dry weight; g: gramme. 
Table 3: Morpho-cultural characteristics of rhizobia isolates for each grain legumes.

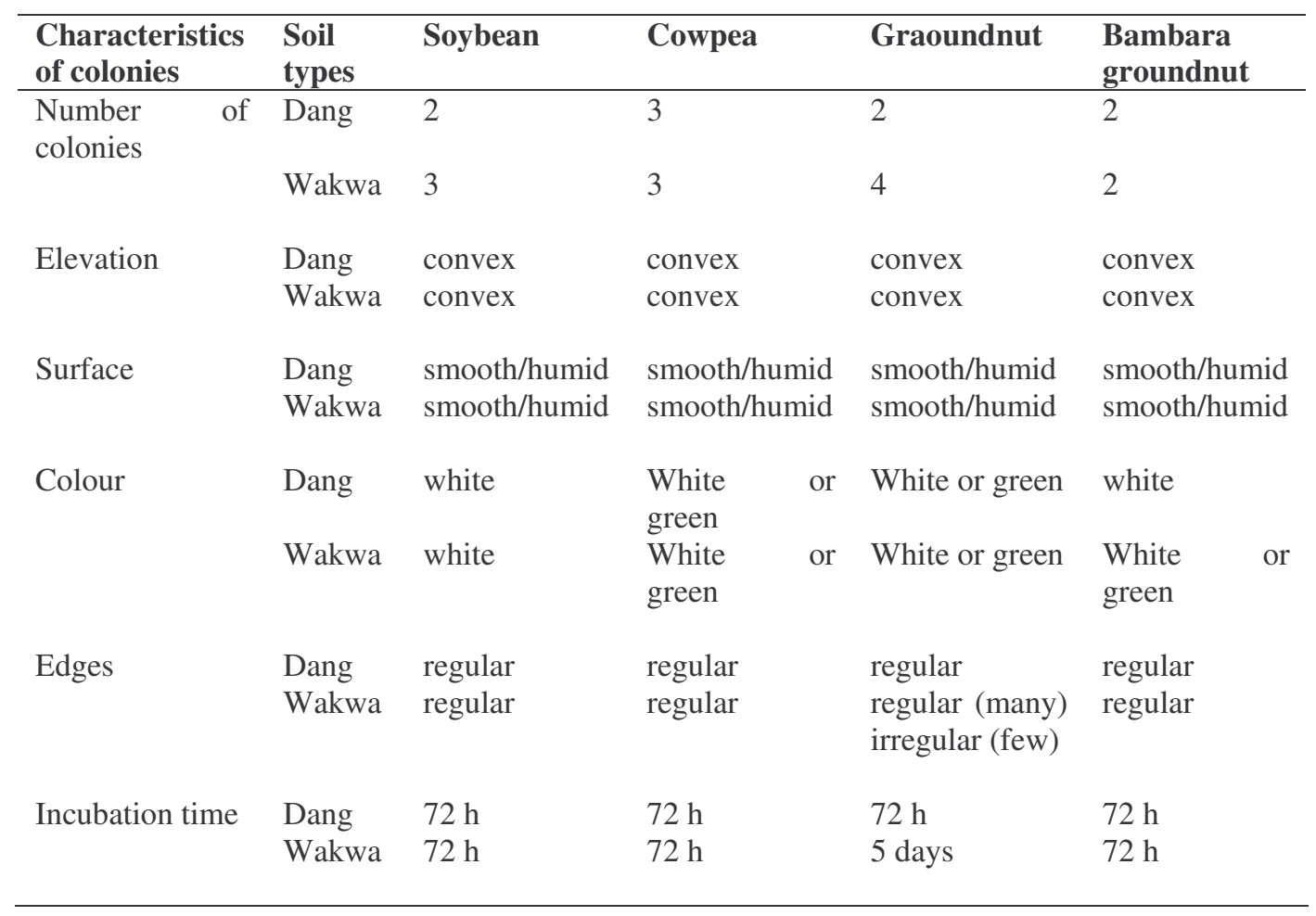

observed respectively in Dang and Wakwa soils. There were two and three different colonies for soybean respectively in Dang and Wakwa, while four were observed for groundnut in each of the soil type. The elevation was convex for all the isolated colonies. Their surface was convex, smooth or humid. The edges of colonies were regular for all the colonies, except for one groundnut colony from Wakwa soil which had irregular edge. The colonies were either whitish for soybean in the two soils, whitish or yellowish for cowpea and groundnut, whitish in Dang soil, whitish or yellowish in Wakwa soil for bambara groundnut. All the colonies took $72 \mathrm{~h}$ to show growth on YEMA-Congo Red solid medium, except for groundnut colonies which were observed only 5 days after incubation. These results suggest that the symbiotic partners associated with groundnut are slower growing than those of other three grain legumes.

\section{Rhizobia biofertilizer}

All the selected rhizobia isolated from grain legume species Glycine $\max$ (L.) Arachis hypogea (L.), Vigna unguiculata (L.) Walp, Vigna subterranea (L.) Verdc were mixed to the carrier substrates to form bioinoculants as shown in Figure 1. These fertilizers were stored in $70 \mathrm{~g}$ transparent white plastic bags, and kept at room temperature for field tests as alternative to nitrogen fertilizers for improving grain legumes production in the region.

\section{DISCUSSION}

Rhizobia including Rhizobium and Bradyrhizobium are best known as biological nitrogen fixers in the root nodules of legumes (Kiers et al., 2003; Denison and Kiers, 2004). In the Guinea-savannah zone of Cameroon, the number of nodule formed in cowpea was already reported to be low (Ngakou, 2007), with nodules starting to degenerate as from 50 days after planting. Soybean showed the highest ability to fix atmospheric nitrogen 
A. NGAKOU et al. / Int. J. Biol. Chem. Sci. 3(5): 1078-1089, 2009

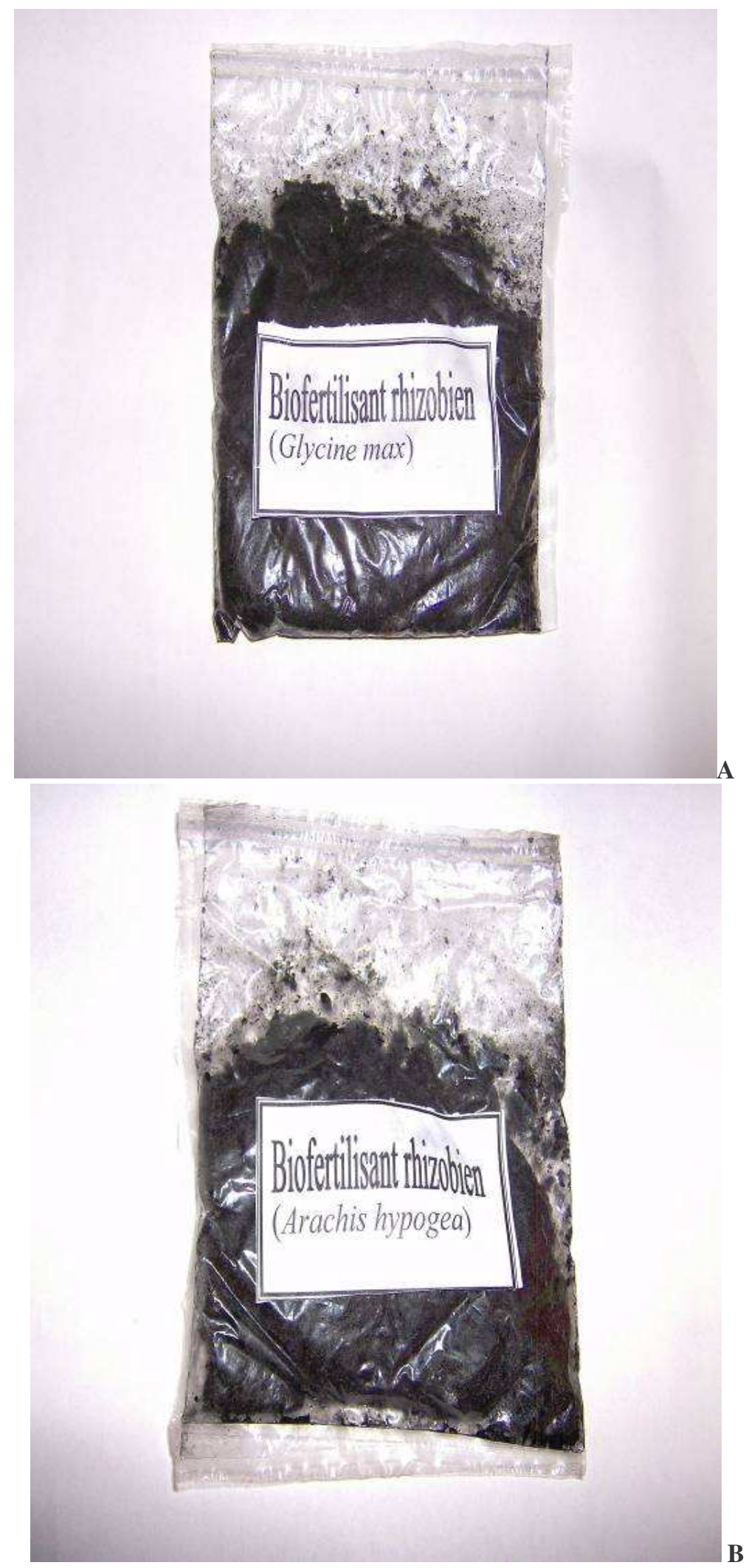

1084 


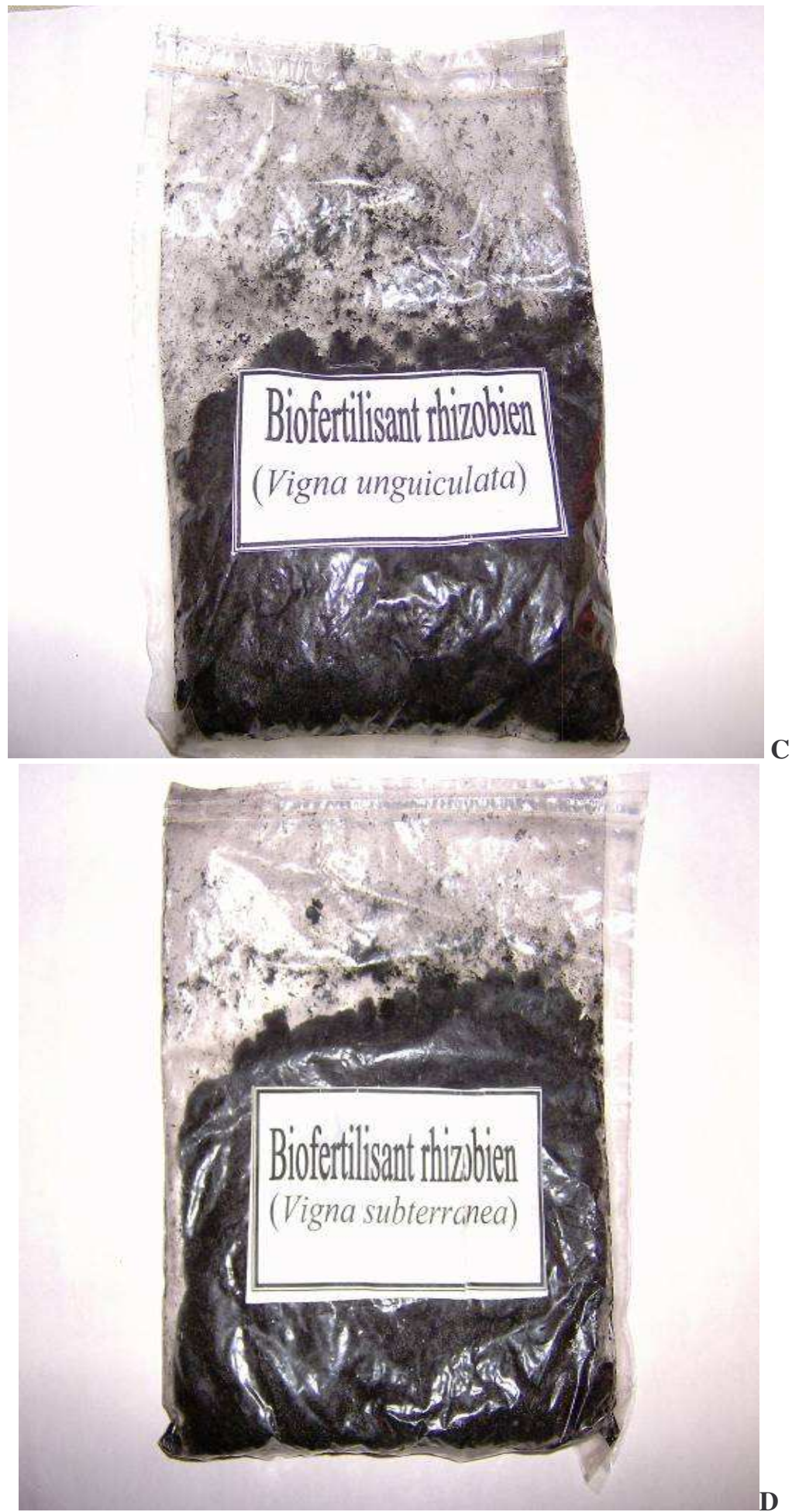

Figure 1: Rhizobia fertilizers for grain legumes production in Ngaoundéré. A: Soybean (70g); B: Groundnut (70g); C: Cowpea (70g); D: Bambara groundnut (70g). 
through its greater nodule efficiency in both Dang and Wakwa soils suggesting the abundance of rhizobia strains able to express a relatively high affinity to this grain legume in the soil. Native rhizobia partners were recently found to be more competitive than a mixture of inoculants within these soils (Megueni et al., 2006). The greater soybean nodules biomass in the two experimental soils was attributed to the large size nodules formed by this grain legume, similar to recent findings reported in cowpea (Ngakou et al., 2007). These results are in agreement with those of Thao et al. (2002) who reported $671 \mathrm{mg}$ dry weight of nodules in the local «MTD-176» soybean variety in Vietnam, but contradict those of Ames et al. (1991), Daniels-Hylton and Ahmad (1994) who attributed increased nodules dry weight to increased nodules number. The number of grain legume nodules obtained in this study was not as high as the abundant nodulation reported in soybean (Hungria et al., 2001), and Pisium (Ballard et al., 2004). This can be attributed to the fact that our experiment was conducted in plastic bags whereas those of Hungria and Ballard were carried out under field conditions. In plastic bags, the growing area of the root system seems to be restricted and this has a direct negative effect on nodule production, thus on the plant growth.

The positive correlations between nodule and plant dry weight was similar to those reported by other authors (Thiagarajan et al., 1992; Hungria et al., 2001). The efficiency of nodules varied from 46 to $89 \%$ for all the four grain legumes, within the range of 40-90\% obtained in Lutus (Baraibar et al., 1999). There was a significant correlation between the efficiency of nodules and the plant biomass, supporting the improved nitrogen fixation potential of the host grain legume that usually lead to increased soil fertility. Through their symbiotic abilities, grain legumes can also play a crucial role in colonizing disturbed ecosystems, including those that are fire-prone (Arianoutsou and Thanos, 1996). They account for $27 \%$ of the world's primary crop production, contributing alone for $33 \%$ of the dietary protein nitrogen (N) needs of humans (Vance et al., 2000). Grain legume seeds generally contain $20 \%$ to $30 \%$ protein, are lysine-rich, and complementing the nutritional profiles of cereals and tubers in the diet (Duranti and Gius, 1997). All these attributes can account for their increased growth.

Inoculation is important to all legumes, especially under planting situations where soil has not previously grown the specific legume. Another factor to be considered is the long time interval (six months to one year) between the planting of successive legume crops. During this period, soil erosion might have removed or depleted bacterial populations or levelling might have exposed lower soil profiles which contain low bacterial populations (Thompson, 1983). The factors influencing the grain legumes-rhizobia symbiosis have been reported to include nutrient constraints particularly nitrogen $(\mathrm{N})$ and phosphorus (P) deficiency, soil acidity, including aluminium (Al) and manganese (Mn) toxicity, and drought. All these factors affect strain variation in nodulation and nitrogen $\left(\mathrm{N}_{2}\right)$ fixation, host strain interaction (Graham et al., 2003). Organic matter appeared critical for maintenance of high populations of indigenous rhizobia in the soils (Mapfumo et al., 2000). This can fully account for the different responses observed between the two soils on the one hand and grain legumes on the other.

The morpho-cultural characteristics of colonies observed in this study confirm that all isolates belong to the genus rhizobia (Larpent and Larpent-Gourgaud, 1985). Each grain legume was infested by at least two different isolates, and might suggest the multistrains interactions with the host plant species. Only one strain isolated from groundnut was found to show growth on YEMA solid medium 5 days after inoculation, suggesting the slow-growth nature of these rhizobia. Conversely, the other rhizobia isolates from bambara groundnut, cowpea and soybean were considered as fast-growing strains with growth occurring $72 \mathrm{~h}$ after inoculation. Similar results were obtained by Mbenoun (1992) on cowpea and soybean. Some of the claimed advantages of using fast-growing strains for grain legume inoculation include the facility of commercial production, easier establishment in soil, and displacement of indigenous strains (Buendia-Clavenia et al., 1994). A similar inoculum produced on whey 
as carrier substrate (Bissonnette et al., 1986), and a mixture of inoculum for legumes (Nwaga, 1997) were previously reported. Rhzobia inoculum are generally very sensitive and unable to live long in dry conditions, so, our grain legume species specific rhizobia inoculum were stored in a cool place, preferably in the refrigerator at $4-5{ }^{\circ} \mathrm{C}$, until needed for re-inoculation assays in order to confirm the nodulation ability of the isolates.

\section{Conclusions}

In the Guinea-Savannah zone of Cameroon, farmers still ignore the inoculation technology and this appears to explain the low yield they obtain from crops. Fertilizer containing rhizobia can be considered as a cheaper and environmentally friendly alternative to the resource poor farmers who cannot afford the expensive artificial $\mathrm{N}$ fertilizer. However, further research is needed to determine whether rhizobia isolated within nodules of the same grain legume species belong or not to the cross-inoculation groups. This information will increase our knowledge on the establishment of the mutual interactions between grain legumes and rhizobia in the region. Re-inoculation of plant species under controlled conditions will confirm these interactions through Koch's postulates, then, identification of isolates will refine characterization of strains as the prerequisite for manufacturing elite commercial inoculum production to grain legumes in the region.

\section{ACKNOWLEDGEMENTS}

The authors wish to specially thank the Laboratory of the Institute of Agricultural Research and Development (IRAD, WakwaNgaoundéré) for providing the logistic facilities that enabled the achievement of this study.

\section{REFERENCES}

Ames RN, Thiagarajan TR, Ahmad MH, Mclaughlin WA. 1991. Co-selection of competitive rhizobia and arbuscular mycorrhizal fungi for cowpea in sterilised and non-sterilised soils. Biol. Fertil. Soils, 12: 112-116.

Arianoutsou M, Thanos CA. 1996. Legumes in the fire-prone Mediterranean regions: an example from Greece. Int. J. Wildland Fire, 6: 77-82.

Arshad M, Frankenberger WT. 1993. Microbial production of plant growth regulators. In Soil Microbial Ecology: Applications in Agricultural and Environmental Management. Metting RB (ed). Marcel Dekker Inc.: New York; 307-348.

Athar M, Johnson AD. 1996. Influence of drought on competition between selected Rhizobium meliloti strains and naturalized soil rhizobia in Alfalfa. Plant Soil, 184: 131-241.

Ballard RA, Charman N, McInnes A, Davidson JA. 2004. Nitrogen fixation in Australian agricultural systems: 13th Australian Nitrogen Fixation Conference Size, symbiotic effectiveness and genetic diversity of field pea rhizobia (Rhizobium leguminosarum bv viciae) populations in South Australian soils. Soil Biol. Biochem., 36(8): 1347-1355.

Baraibar A, Frioni L, Guedes ME, Junggreen HL. 1999. Symbiotic effectiveness and ecological characterization of indigenous Rhizobium loti population in Uruguay. Pesq. Agropec. Brasilia, 34(4): 10111017.

Bissonnnette N, Lalande R, Bordeleau LM. 1986. Large-scale production of Rhizobium meliloti on whey. Appl. Env. Microbiol., 52(4): 838-841.

Buendia-Claveria AM, Rodriguez-Navaro DN, Santamaria-Linaza C, Ruiz-Sainz JE, Temprano-Vera F. 1994. Evaluation of the symbiotic properties of Rhizobium fredii in European soils. Syst. Appl. Microbiol., 17: 155-160.

Cheng Y. 2003. Plant mechanisms contributing to acid impairment of nodulation of Medicago murex and Medicago sativa by Sinorhizobium medicae. Ph.D thesis, Murdoch University. 180p.

Daniel-Hylton KDM, Ahmad MH. 1994. Inoculation response in Kidney bean (Phaseolus vulgaris, L) to vesiculararbuscular mycorrhiza fungi and rhizobia in non sterilized soil. Biol. Fertil. Soils, 18: $95-98$.

Denison RF, Kiers ET. 2004. Why are most rhizobia beneficial to their plant hosts, 
rather than parasitic? Microbes Infection, 6: 1235-1239.

Duranti M, Gius C. 1997. Legume seeds: protein content and nutritional value. Field Crops Res., 53: 31-45.

Graham PH, Rosasb JC, Estevez de Jensenc C, Peraltad E, Tlustya B, AcostaGallegose J, Arraes Pereiraf PA. 2003. Addressing edaphic constraints to bean production the Bean/Cowpea CRSP project in perspective. Field Crops Res., 82(2-3): 179-192.

FAO. 1985. Inoculum for Legumes and their Applications. NIFTAL: Rome; 63p.

Hirsch AM, Lum MR, Downie JA. 2001. What makes the rhizobia-legume symbiosis so special? Plant physiol., 127: 1484-1492.

Hungria M, Campo RJ, Chueire LMO. 2001. Symbiotic effectiveness of fast-growing rhizobia strains isolated from soybean nodules in Brazil. Biol. Fertil. Soils, 33: 387-394.

Hynes RK, Jans DC, Bremer E, Lupwayi NZ, Rice WA, Clayton GW, Collins MM. 2001. Rhizobium population dynamics in the pea rhizosphere of rhizobial inoculant strain applied in different formulations. Can. J. Microbiol., 47(7): 595-600.

Jensen ES, Hauggaard-Nielsen H. 2002. Understanding the role of grain legumes in the $\mathrm{N}$ cycling of agroecosystems. Grain Legumes, 36(2): 12-14.

Kiers ET, West SA, Denison RF. 2002. Mediating mutualisms farm management practices and evolutionary changes in symbiont co-operation. J. Appl. Ecol., 39: 745-754.

Kiers ET, Rousseau RA, West SA, Denison RF. 2003. Host sanctions and the legume-Rhizobium mutualism. Nature, 425: 78--81.

Kober MV, Sã ELS, Freire JRJ, Giongo A. 2004. Characterization of variant of Bradyrhizobium elkanii and B. japonicum and symbiotic behaviour in soybeans. Ciencia Rural, Santa Maria, 34(5): 14591464.

Larpent J.P, Larpent GM. 1985. Practical Manual of Microbiology. Hermann Collection Methods: Paris ; p.230.

Linderman WC. 2008. Nitrogen fixation by legume. Guide A-129. Cooperative
Extension Service, College of Agriculture and Home Economics, New Mexico State University, p.3.

Lupwayi NZ, Kennedy AC. 2007. Grain legumes in northern Great Plains. Impacts on selected biological soil processes. Agron. J., 99: 1700-1709.

Mapfumo SP, Mpepereki S, Mafongoya P. 2000. Pigeonpea rhizobia prevalence and crop response to inoculation in Zimbabwean smallholder-managed soil. Exp. Agric., 36: 423-434.

Mbenoun LE. 1992. Characterization of Bradyrhizobium sp of cowpea and bambara groundnut isolated from diverse agro-ecologic zones of Cameroon. MSc. dissertation, University of Yaounde, 65p.

Megueni C, Ngakou A, Makalao MM, Kameni TD. 2006. Responses of soybean (Glycine max L.) to soil solarization and rhizobial field inoculation at Dang, Ngaoundéré, Cameroon. Asian J. Plant Sci., 5(5): 832-837.

Ngakou A. 2007. Potentials of selected biofertilizers and a mycoinsecticides in managing Megalurothrips sjostedti and improving cowpea production in Cameroon. Ph.D. thesis, Department of Biochemistry and Microbiology, Faculty of Life Sciences, University of Buea, p. 197.

Ngakou A, Nwaga D, Ntonifor NN, Tamo M, Nebane CLN, Parh IA. 2007. Contribution of Arbuscular Mycorrhizal Fungi (AMF), rhizobia and Metarhizium anisopliae to cowpea production in Cameroon. Int. J. Agric. Res., 2(9): 754764.

Nwaga D., 1997. Pilot production of rhizobia and mycorrhiza biofertilizers in Cameroon: interest and constraints. Cam. J. Biol. Biochem. Sci., 7: 16-23.

Ogendo AOM, Joshua O. 2001. Response of common bean to Rhizobium inoculation and fertilizers. J. Food Technol. Afric., 6(4): 121-125.

Pal UR, Shehu Y. 2001. Direct and residual contributions of symbiotic nitrogen fixation by legumes to the yield and nitrogen uptake of maize (Zea mays L.) in the Nigerian savannah. J. Agron. Crop Sci., 187(1): 53-58. 
Seeley HWS, VanDemark JrPJ. 1989. Microbe in Action. A Laboratory Manual of Microbiology (3rd edn). Freeman and Company: San Francisco; p.199.

Somasegaram P, Hoben HJ. 1985. Method in Legume-Rhizobium Technology. Niftal Muircen Hawaï: USA; p.365.

Simms EL, Taylor DL. 2002. Partner choice in nitrogen-fixation mutualisms of legumes and rhizobia. Integrated Comp. Biol., 42: 369-380.

Thao TY, Paul WS, David H. 2002. Inoculation responses of soybean and liquid inoculants as an alternative to pestbased inoculant. In Inoculants and Nitrogen Fixation of Legumes in Vietnam. Herridge D (ed). ACIAR Proceeding; 2936.

Thompson JA. 1983. Production and quality control of carrier-based legume inoculants. Information Bulletin $\mathrm{N}^{\circ} 17$ of the International Institute for the SemiArid Tropic (ICRISAT), India, p.18-27.

Thiagarajan TR, Armes, RN, Ahmad MH. 1992. Response of cowpea (Vigna unguiculata L.), Walp. to inoculation with co-selected AMF and Rhizobium strains in field trials. Can. J. Microbiol., 38: 573-576.

Vance CP, Graham PH. 1995. Nitrogen fixation in agriculture: application and perspectives. In Nitrogen Fixation: Fundamentals and Applications. Tikhonovich VI, Newton WE (eds). Kluver Academic Publisher, The Netherlands; 77-86.

Vance CP, Graham PH, Allan DL. 2000. Biological nitrogen fixation. Phosphorus: a critical future need. In Nitrogen Fixation: From Molecules to Crop Productivity. Pedrosa FO, Hungria M, Yates MG, Newton WE (eds). Kluwer Academic Publishers. Dordrecht, The Netherlands; 506-514.

Vessey JK. 2003. Plant growth promoting rhizobacteria as biofertilizers. Plant Soil, 255: 571-586.

Vincent JM. 1970. A Manual for the Practical Study of Root-Nodule Bacteria. International Biological Programm Hanbook No. 15. Blackwell Scientific Publications: Oxford, UK.

Zahran HH. 1999. Rhizobium-legume symbiosis and nitrogen fixation under servere conditions in an arid climate. Microbiol. Mol. Biol. Rev., 63(4): 968989.

Zdor RE, Pueppke SG. 1990. Competition for nodulation of soybean by Bradyrhizobium japonicum 123 and 138 in soil containing indigenous rhizobia. Soil Biol. Biochem., 22: 606-613. 